\title{
Penerapan E-Commerce Dalam Meningkatkan Daya Saing Usaha
}

\author{
Alwendi \\ Universitas Graha Nusantara \\ alwendi60@gmail.com
}

\begin{abstract}
ABSTRACK
The objectives of the study are to: (1) analyze any motives that drives entrepreneurs use ecommerce; (2) reviewing the benefits of e-commerce for entrepreneurs and; (3) analyze the barriers of entrepreneurs in implementing e-commerce. The result indicates that the motive of entrepreneurs in implementing e-commerce are accessing global markets $56 \%$, promoting the product $63 \%$, branding $56 \%$, close to the customers $74 \%$, helps communication quickly to customers $63 \%$ and satisfying the customers $56 \%$. Beside, the benefits are satisfying the customers $74 \%$ and competitive advantage $81 \%$. The barriers faced by entrepreneurs are the lack of human resources $40 \%$, the high cost of $20 \%$, licensing difficulties $20 \%$, and business network $20 \%$.
\end{abstract}

\section{Keywords: Micro Business; Communication; Networking, Global}

\begin{abstract}
ABSTRAK
Tujuan dari penelitian ini adalah untuk: (1) menganalisis motif apa pun yang mendorong pengusaha menggunakan e-commerce; (2) meninjau manfaat e-commerce untuk pengusaha dan; (3) menganalisis hambatan pengusaha dalam menerapkan e-commerce. Hasil mencerminkan bahwa motif pengusaha dalam menerapkan e-commerce mengakses pasar global $56 \%$, mempromosikan produk $63 \%$, merek $56 \%$, dekat dengan pelanggan $74 \%$, membantu komunikasi dengan cepat ke pelanggan $63 \%$ dan memuaskan pelanggan $56 \%$. Selain itu, manfaatnya memuaskan pelanggan $74 \%$ dan keunggulan kompetitif $81 \%$. Hambatan yang dihadapi oleh pengusaha adalah $40 \%$ kekurangan sumber daya manusia, tingginya biaya $20 \%$, kesulitan perizinan $20 \%$, dan jaringan bisnis $20 \%$.
\end{abstract}

Kata Kunci : Usaha Mikro; Komunikasi; Jejaring; Global 


\section{PENDAHULUAN}

Dewasa ini perkembangan tekhnologi informasi begitu pesat. Sebut saja perkembangan telepon atau telepon seluler dan internet, keberadaannya memberikan pengaruh bagi berbagai aspek kehidupan. Baik kehidupan secara individu, sosial maupun yang terkait dengan dunia usaha atau bisnis. Selain mempermudah dan mempercepat proses komunikasi dan informasi, teknologi informasi juga dimanfaatkan dalam kegiatan usaha atau bisnis. Banyak alat komunikasi dan informasi yang digunakan dalam kegiatan dunia usaha, seperti penggunaan telepon, fax, sms, email, website dan lain-lain. Sehingga munculah istilah “e-commerce”. Ecommerce (electronic commerce) adalah proses transaksi jual beli dengan menggunakan alat elektronik, seperti telepon dan internet. Shim et al. (2000) dalam Suyanto (2003) mendefinisikan e-commerce (electronic commerce) sebagai konsep baru yang bisa digambarkan sebagai proses jual-beli barang atau jasa pada World Wide Web Internet. Atau menurut Turban dkk (2008) e-commerce merupakan jual beli atau pertukaran produk, jasa dan informasi melalui jaringan informasi termasuk internet. Sedangkan menurut Kalakota dan Whinston (1997) mendefinisikan e-commerce dari beberapa perspektif berikut:

1. Perspektif komunikasi: e-commerce merupakan pengiriman informasi, produk/layanan, atau pembayaran melalui lini telepon, jaringan komputer atau sarana elektronik lainnya.

2. Perspektif proses bisnis: e-commerce merupakan aplikasi teknologi menuju otomisasi transaksi dan aliran kerja perusahaan.

3. Perspektif layanan: e-commerce merupakan salah satu alat yang memenuhi keinginan perusahaan, konsumen dan manajemen dalam memangkas service cost ketika meningkatkan mutu barang dan kecepatan pelayanan.

4. Perspektif online: e-commerce berkaitan dengan kapasitas jual beli produk dan informasi di internet dan jasa online lainnya.

Penggunaan e-commerce pada saat ini merupakan syarat bagi sebuah organisasi atau perusahaan, agar perusahaan itu dapat bersaing secara global. Banyak penelitian yang menekankan efisiensi dalam penggunaan e- commerce. Selain itu juga peneliti banyak melihat dampak positif yang diberikan oleh e- commerce dibandingkan dampak negatifnya. Sekarang banyak perusahaan, baik perusahaan kecil atau perusahan besar memanfaatkan e-commerce sebagai upaya meningkatkan bisnisnya. Berdasarkan penelitian dan studi kasus di Australia (Burges, et al, 2003), ada beberapa faktor yang mendorong perusahaan dalam memanfaatkan 
e-commerce: (1) penggunaan komputer dan teknologi informasi oleh sebuah perusahaan (2) Penerapan e-commerce saat ini, dan rencana dimasa yang akan datang (3) kendala dalam penggunaan e-commerce (4) keahlian dari staff teknologi informasi pada sebuah perusahaan.

E-commerce setidaknya memberikan enam buah dampak positif bagi operasi bisnis suatu perusahaan (Yau, 2002; Widani, et al, 2019; Dewi dan Darma, 2014). Keenam dampak tersebut yaitu: meningkatkan efisiensi, penghematan biaya, memperbaiki kontrol terhadap barang, memperbaiki rantai distribusi (supply chain), membantu perusahaan menjaga hubunganyang lebih baik terhadap pelanggan dan membantu perusahaan dalam menjaga hubungan yang lebih baik terhadap pemasok (supplier). Adapun kendala yang dihadapi, dan merupakan sebuah tantangan bagi kita sekarang ini adalah mengenai sekuritas dan metode pembayaran (Youssef, dan Soliman, 2003; Pranata dan Darma, 2014; Mahyuni et al, 2020). Dengan perkembangan teknologi internet, diharapkan masalah tersebut akan semakin terkendali untuk masa yang akan datang. Penggunaan e-commerce merupakan sebuah keharusan dalam dunia usaha, mengingat masalah yang semakin kompleks, kompetitor yang semakin menjamur dan tuntutan untuk selalu mengikuti perkembangan dunia global yang mengharuskan untuk selalu bertindak kreatif. Diharapkan dengan pemanfaatan e- commerce ini memberikan dampak pada akselerasi perkembangan dunia usaha baik usaha skala kecil, menengah maupun kelas atas. Dampak positif ini tentu akan dirasakan apabila perusahaan dapat menggunkan e- commerce dengan tepat dan disesuaikan dengan jenis dan karakter usahanya. Salah satu fungsi dari pemanfaatan e- commerce ini adalah adanya efisiensi terhadap dunia usaha. Baik efisien secara materil (biaya) maupun secara non-materil (tenaga dan waktu). Dari segi biaya, perusahaan dapat menekan biaya misalnya dengan me- manfaatkan telepon dan internet sebagai media penawaran dan promosi barang atau jasa. Karena hal tersebut akan lebih murah dibandingkan dengan cara tradisional atau offline. Di sisi lain, efisiensi biaya ini juga bisa terjadi karena adanya pengurangan tenaga kerja pada posisi tertentu. Selain itu, penggunaan e-commerce juga dapat menekan waktu kerja. Hal ini terjadi misalnya dengan pemanfaatan fax dan email dalam mengirimkan berbagai surat bisnis. Dengan demikian, pemanfaatan e-commerce selain berimplikasi pada peningkatan pelayanan terhadap pelanggan (konsumen/nasabah) atau klien, juga dapat dimanfaatkan sebagai alat strategi dalam menghadapi kompetitor atau pesaing. Dalam hubungannya terhadap pelayanan kosumen, e- commerce akan mempermudah komunikasi dan transaksi antara penjual dan pembeli. Perkembangan teknologi informasi akibat dari hasil globalisasi juga akan melahirkan apa yang diaggap sebagai "pesaing" atau "kompetitor" yang sangat tajam dalam 
dunia bisnis. Globalisasi ekonomi membentuk perubahan menjadi radikal, serentak, dan pervasif ke dalam berbagai aspek. Perusahaan harus memiliki kemampuan untuk merespons dengan cepat untuk beradaptasi terhadap perubahan yang terjadi sehingga perusahaan mampu dalam menghadapi persaingan yang begitu ketat. Peranan e-commerce diharapkan mampu memberikan manfaat yang signifikan dalam menghadapi dunia bisnis yang penuh persaingan tersebut. Perusahaan yang survive dan konsisten serta cenderung meningkat adalah perusahaan yang mampu menerjemahkan dunia teknologi ke dalam dunia usahanya. Penggunaan ecommerce adalah salah satu bentuk implementasi perkembangan teknologi untuk memasarkan produknya (barang atau jasa) ke segala tempat dan segmen, baik dalam bentuk fisik maupun digital, baik skala nasional maupun internasional.

Selain memberikan dampak positif terhadap perkembangan usaha, e-commerce juga tidak selamanya menguntungkan. Dunia internet yang berkembang pesat dianggap berkontribusi terhadap biaya investasi yang relatif rendah dan mampu mengalirkan modal yang besar, dijadikan sebagai media promosi yang besar-besaran. Promosi besar-besaran dengan harapan banyak mendatangkan mengunjung ternyata tidak selamanya menguntungkan.

\section{METODE PENELITIAN}

Metode penelitian yang digunakan dalam penelitian ini adalah metode deskriptif dengan pendekatan kualitatif. Metode ini terutama digunakan untuk mendeskripsikan bagaimana fenomena aktivitas pelaku usaha dalam memafaatkan $e$-commerce dalam meningkatkan daya saing usahanya.

Analisis data dilakukan secara kualiatatif. Analisis data secara kualitatif, yaitu dengan cara mendeskripsikan jawaban responden yang kemudian disajikan dalam bentuk table, distribusi frekuensi, dan grafik.

\section{HASIL DAN PEMBAHASAN}

Penelitian ini melibatkan 10 responden sebagai sampel. Kesepuluh responden tersebut adalah para pelaku usaha baik dalam bidang perdagangan (barang/produk) maupun yang bergerak di bidang jasa (service) dengan rincian sebagai berikut: $80 \%$ responden adalah para pelaku usaha di bidang perdagangan (barang) dan sisanya sebanyak $20 \%$ adalah para pelaku usaha yang bergerak pada bidang jasa. Komposisi tersebut dapat digambarkan seperti gambar berikut. 


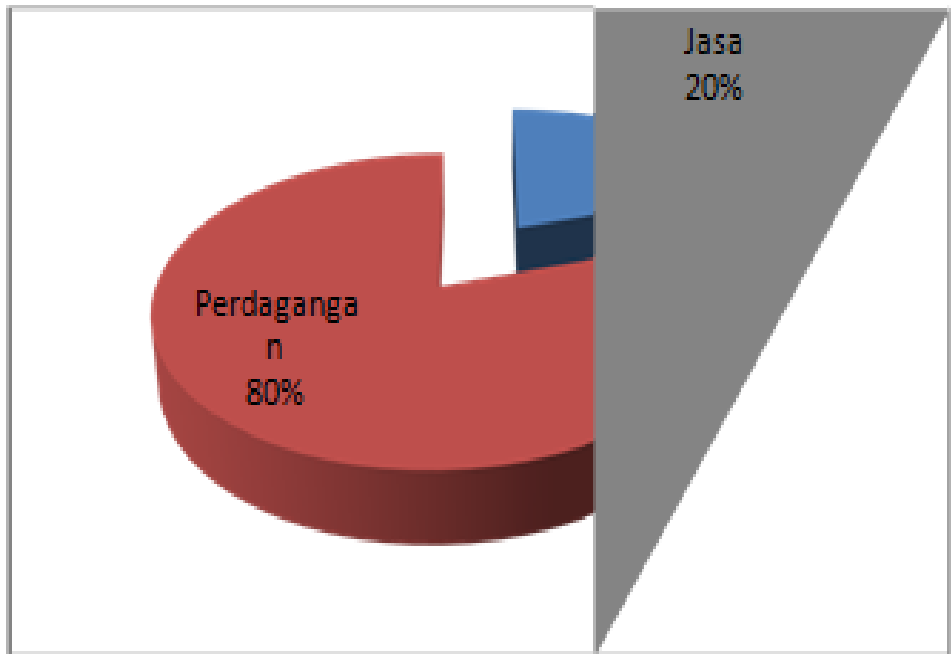

Gambar 1. Jenis Usaha Responden

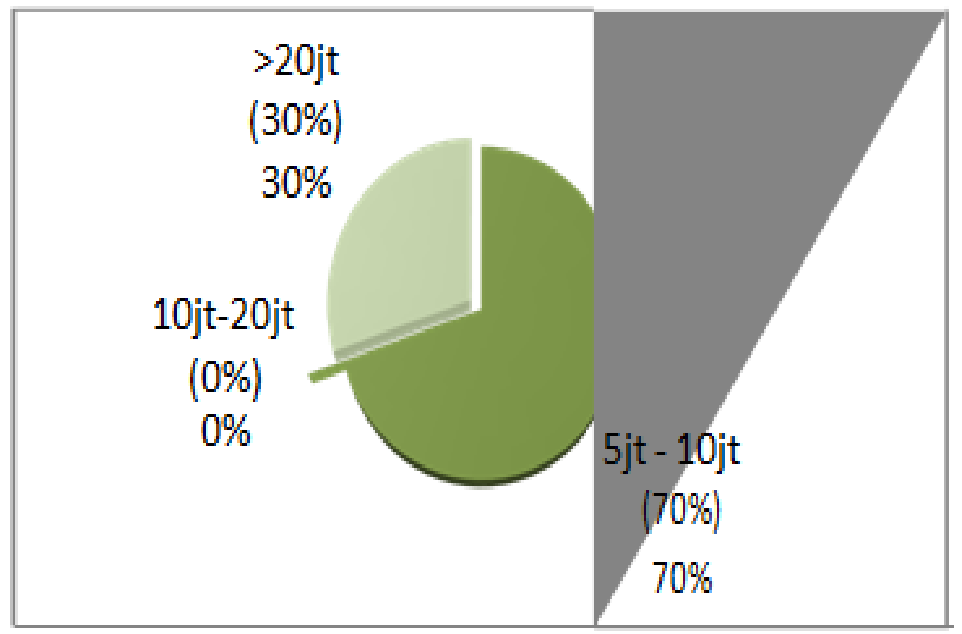

Gambar 2. Omset Usaha

Spesifikasi usaha responden pada bidang pemasok perdagangan adalah: toko pakaian toko elektronik, telepon seluler, produsen kebutuhan industri, dan pemasaran hasil pertanian. Sedangkan usaha responden yang bergerak pada bidang jasa adalah: services komputer/telepon seluler, jasa cuci cepat, jasa pembuatan laman (website) dll. Dilihat jumlah omzet perbulan yang dimiliki, reponden $70 \%$ memiliki omzet pada kisaran Rp 5.000.000 - 10.000.000, sedangkan responden yang memiliki omzet di atas Rp 20.000.000 sebanyak 30 persen Motif responden dalam penerapan e-commerse terhadap usahanya dapat dilihat pada tabel berikut: 


\section{Tabel 1. Pertanyan Pelanggan}

\begin{tabular}{|l|l|l|l|l|l|l|}
\hline NO & \multicolumn{1}{|c|}{ PERTANYAAN } & $\mathbf{1}$ & $\mathbf{2}$ & $\mathbf{3}$ & $\mathbf{4}$ & $\mathbf{5}$ \\
\hline 1 & Mendapatkan Pelanggan Baru & 0 & 0 & 0 & 37 & 65 \\
\hline 2 & Mengakes Pasar Global & 0 & 0 & 11 & 33 & 56 \\
& & & & & & \\
\hline 3 & Mempromosikan Produk & 0 & 0 & 7 & 30 & 63 \\
\hline 4 & Membangun Merk & 0 & 4 & 11 & 56 & 30 \\
\hline 5 & Memberikan Citra Positif pada Perusahaan & 0 & 4 & 15 & 63 & 19 \\
\hline 6 & Membantu dalam bersaing dengan perusahaan besar & 0 & 26 & 19 & 22 & 33 \\
\hline 7 & $\begin{array}{l}\text { Membantu dalam bersaing dengan perusahaan kecil dan } \\
\text { menengah sejenis }\end{array}$ & 7 & 22 & 22 & 37 & 11 \\
\hline 8 & Mendekatkan dengan pelanggan & 0 & 0 & 0 & 26 & 74 \\
\hline 9 & Membantu komunikasi yang lebih cepat dengan pelanggan & 0 & 0 & 15 & 22 & 63 \\
\hline 10 & Memuaskan pelanggan & 0 & 0 & 4 & 41 & 56 \\
\hline 11 & Memberikan pelayanan tanpa batas waktu & 0 & 0 & & 11 & 89 \\
\hline 12 & Membantu transaksi bisnis & 0 & 7 & 48 & 30 & 15 \\
\hline 13 & Mendapatkan pemasok baru & 4 & 41 & 44 & 11 & 0 \\
\hline 14 & Mempermudah komunikasi dengan pemasok & 7 & 37 & 30 & 22 & 4 \\
\hline 15 & Mendapatkan mitra bisnis & 4 & 26 & 11 & 37 & 22 \\
\hline 16 & Mendapatkan distributor atau agen & 0 & 30 & 56 & 11 & 4 \\
\hline 17 & Mengakses informasi dari pihak luar & 0 & 22 & 30 & 37 & 11 \\
\hline 18 & Penghematan biaya & 11 & 44 & 37 & 7 & 0 \\
\hline 19 & Memperbaiki komunikasi internal & 10 & 26 & 44 & 19 & 0 \\
\hline 20 & Membantu dalam proses penarika ntenaga kerja & 30 & 48 & 11 & 7 & 0 \\
\hline 21 & Menghemat biaya pencarian tenaga kerja & 41 & 41 & 11 & 7 & 0 \\
\hline 22 & Efesiensi proses bisnis & 7 & 15 & 22 & 30 & 26 \\
\hline
\end{tabular}

berdasarkan tabel diatas dapat diketahuhi seberapa besar motif perusahaan atau pelaku usaha untuk menerapkan ecommerce. Dimana interval skala 1-5 tersebut mempunyai keterangan: 1 = sangat rendah harapan perusahaan, $2=$ rendah harapan perusahaan, $3=$ netral, $4=$ lumayan, $5=$ sangat tinggi harapan perusahaan.

Berdasarkan tabel 1 dapat dinyatakan bahwa faktor yang melandasi perusahaan terdorong menggunakan e-commerce terdiri dari enam faktor yaitu yang menjadi harapan tertinggi bagi para perusahaan ketika ingin menerapkan e-commerce:

1. Mengakses pasar global $56 \%$

2. Mempromosikan produk $63 \%$

3. Membangun merk $56 \%$

4. Mendekatkan dengan pelanggan $74 \%$

5. Membantu komunikasi lebih cepat dengan pelanggan $63 \%$

6. Memuaskan pelanggan $56 \%$ 
Adapun yang menjadi manfaat terbesar adalah e-commerce dapat meningkatkan omzet penjualan hal tersebut dapat dilihat dengan presentase sebesar 31\%. Manfaat berikutnya adalah peningkatan jumlah pelanggan dengan presentase sebesar 24\%. Studi yang menyebutkan bahwa manfaat penggunaan e- commerce dalam bisnis adalah mendapatkan pelanggan baru dikemukakan oleh Hamill dan Gregory (1997) dan Swatman (1999) serta Hoffman dan Novak (2000). Digunakannya e- commerce memungkinkan perusahaan tersebut mendapatkan pelanggan baru baik itu yang berasal dari pasar domestik maupun pasar luar negeri.

Manfaat berikutnya adalah perluasan jangkauan bisnis serta sarana promosi dengan persentase masing-masing 16\%, serta peluang terbukanya bisnis baru dan kepuasan pelanggan sama rata yaitu $5 \%$, dan yang terakhir adalah kemudahan hubungan relasi yaitu hanya $2 \%$.

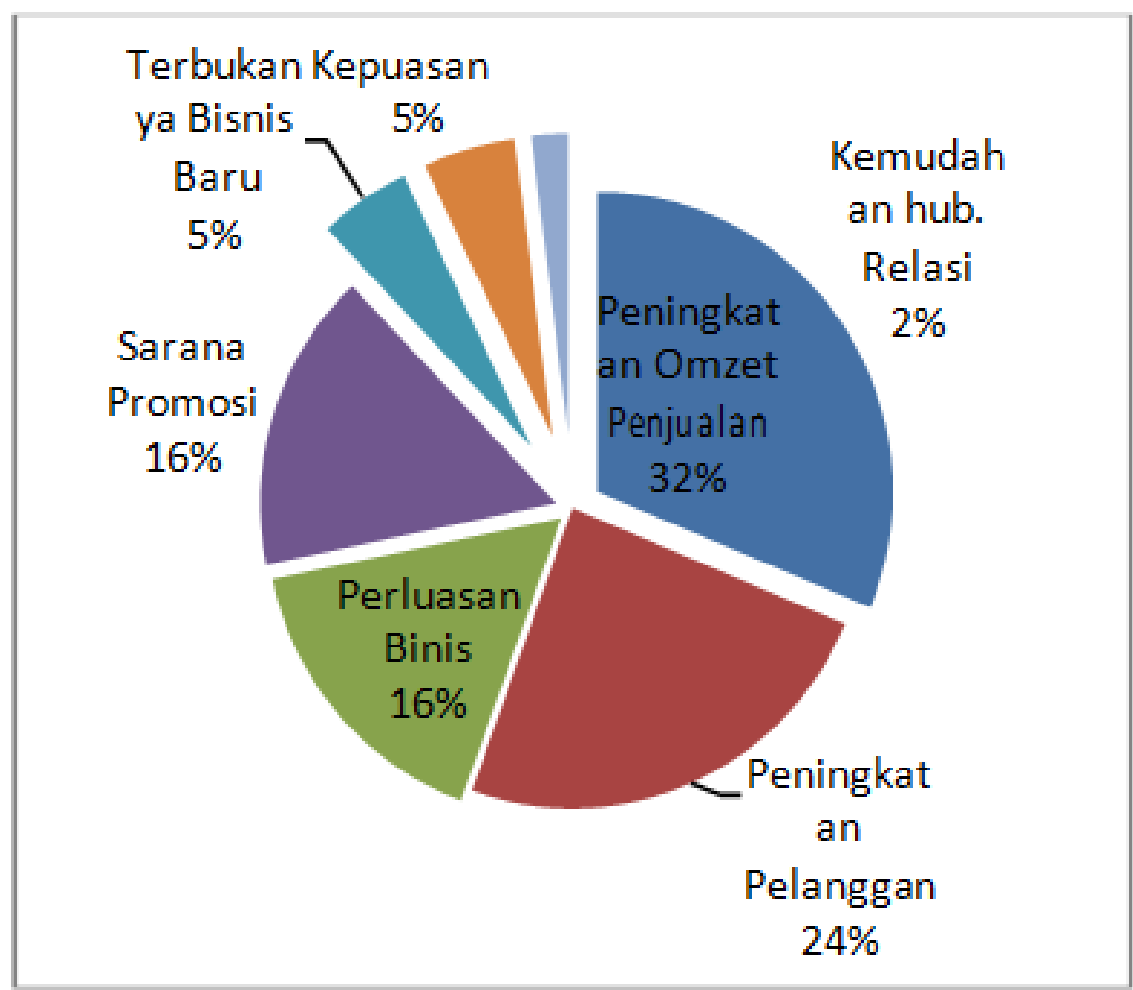

Gambar 3. Manfaat E-Commerce

Dalam penggunaan e-commerse, pelaku usaha sering mengahadapi kendala. Kendalakendala yang sering dihadapi di antaranya adalah masalah sumber daya manusia, perijinan, jaringan, pemasaran (marketing), dan biaya. Kendala sumber daya manusia dan biaya memiliki persentase yang tinggi yaitu 40\%, artinya responden masih memiliki hambatan sumber daya manusia dan biaya dalam penerapan e-commerse. Hal ini dimungkinkan masih minimnya sumber daya manusia yang menguasai tekhnologi khususnya ecommerse.

Selain itu, peralatan dan perawatan yang diperlukan dalam penerapan e-commerse juga membutuhkan biaya yang sangat tinggi. Sedangkan untuk masalah atau hambatan jaringan, 
perijinan, dan marketing dengan persentase masing-masing sebesar 20\%. masalah perijinan ini menurut beberapa perusahaan disebabkan masalah birokrasi perijinan dari lingkungan sekitar yang sangat sulit.

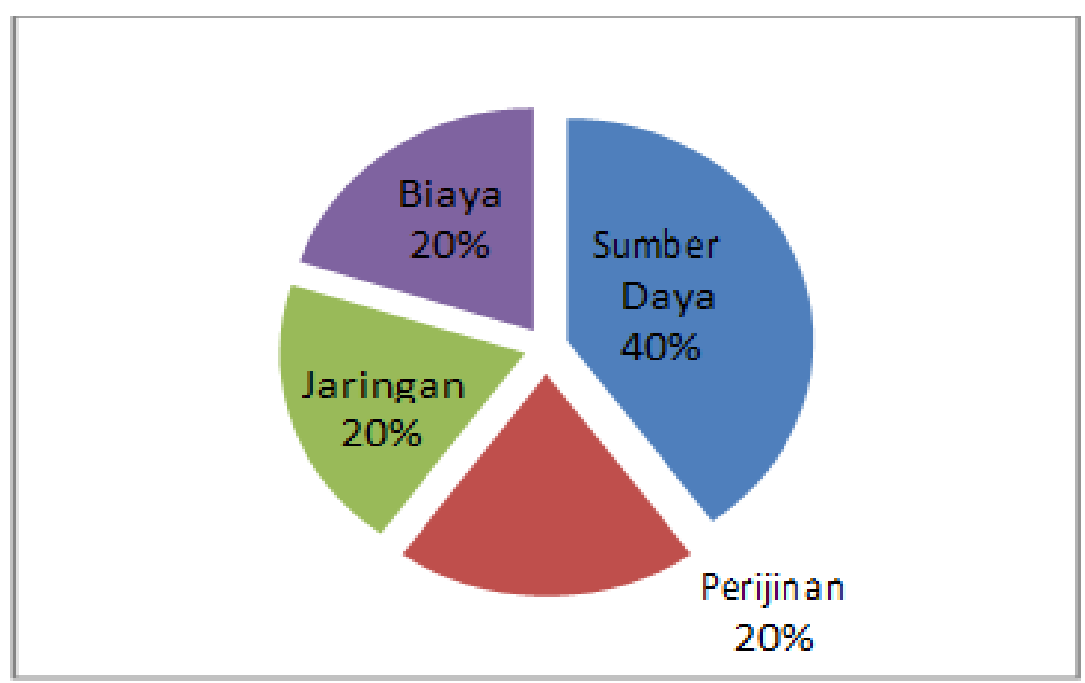

Gambar 4. Hambatan dalam Penggunaan E-Commerce

\section{PENUTUP}

Sebagai upaya mengembangkan bisnis, banyak hal yang perlu dilakukan, salah satunya adalah dengan menerapkannya sistem e- commerse. E-commerse dalam dunia usaha adalah penggunaan tekhnologi terkini seperti internet dalam memudahkan kegiatan-kegiatan bisnis. Melalui internet pelaku usaha dapat dengan mudah berkomunikasi dan surat menyurat melalui email, chating, dan lain sebagainya. Dapat mempromosikan produk melalui iklan online, juga dapat memperkenalkan perusahaan dan mencari pelanggan baru melalui laman (website).

Dari hasil pembahasan sebelumnya, motif pelaku usaha dalam menerapkan ecommerse adalah: Mengakses Pasar global, mempromosikan produk, membangun merk, mendekatkan dengan pelanggan, membantu komunikasi lebih cepat dengan pelanggan, dan dalam rangka memuaskan pelanggan. Sedangkan manfaat yang diarasakan oleh pelaku usaha ketika menerpakan ecommerse adalah: meningkatkan omzet penjualan, meningkatkan jumlah pelanggan, sebagai sarana promosi, dan dapat memperluas bisnis. Dalam menerpakan ecommerse, ada beberapa kendala yang sering dihadapi oleh para pelaku usaha, diantaranya adalah: lemahnya sumber daya manusia, mahalnya biaya, sulitnya mendapat perizinan, dan terkendala oleh hambatan jaringan. 


\section{DAFTAR PUSTAKA}

Burgess, et al. (2003). Factors Affecting Adoption of Electronic Commerce Technologies by SMEs: an Australian Study, Journal of Small Business and Enterprise Development, $10(3)$.

Dewi, C.R., and Darma, G.S. (2014). Website Usability, Satisfaction, Loyalty, Security Perception, Trust, and Word of Mouth in e-Commerce Business, Jurnal Manajemen \& Bisnis, 11 (2): 1-30.

Daniel, E., and Wilson, H. (2002). Adoption Intentions and Benefits Realised : A study of e commerce in UK SMEs, Journal Of Small Business and Enterprise Development, 9 (4): 331-348.

Daniel, Mc., dan Gates. (2001). Riset Pemasaran Kontemporer. Jakarta : Salemba Empat.

Hamill, J., and Gregory, K. (1997). Internet Marketing in the Internationalization of UK SMEs, Journal of Marketing Management, 13: 9-28.

Kalakota dan Whinston. (1996). Frontiers Of Electronic Commerce. Massachusetts: AddisonWesley Publilshing Company, Inc.

Mahyuni, L.P., Adrian, R., Darma, G.S., Krisnawijaya, N.N.K., Dewi, I.G.A.A.P., and Permana, G.P.L. (2020). Mapping the potentials of blockchain in improving supply chain performance, Cogent Business \& Management, 7 (1788329): 1-18. https://doi.org/10.1080/23311975.2020.1788329

Pranata, I.M.A., and Darma, G.S. (2014). Strategi Penerapan E-Commerce Dalam Meningkatkan Keunggulan Bersaing, Jurnal Manajemen \& Bisnis, 11 (1): 69-81.

Suyanto, M. (2003). Strategi Periklanan pada E- Commerce Perusahaan Top Dunia. Yogyakarta : Andi.

Santosa, S. (2017). E-Commerce Tantangan Kompetensi Akuntan dalam menghadapi Isu Internal Kontrol, 4 (1).

Soliman, F., dan Youssef, M.A. (2003). Internet-Based E-commerce and Its Impact on Manufacturing and Business Operation, Industrial Management \& Data Systems, 103 (8).

Widani, N.M., Abiyasa, A.P., Darma, G.S. (2019). Menguji Ketajaman Implementasi ECommerce Dalam Penjualan Kamar Hotel di Bali, Jurnal Manajemen \& Bisnis, 16 (2): 79-98. 